
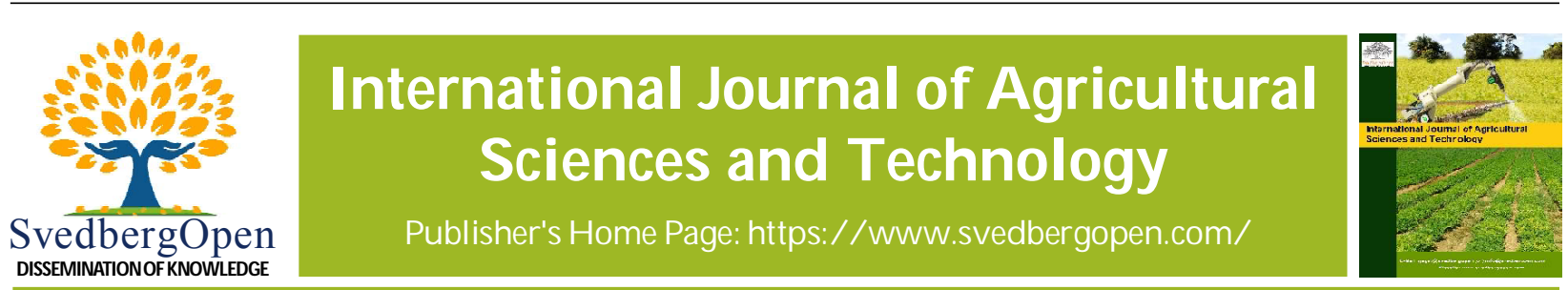

\title{
Evaluation of toxicity of five medicinal plant extracts on maize weevil, Sitophilus zeamais (Mots.) (Coleoptera: Curculionidae) on stored maize
}

\author{
Fatematuzzjohora ${ }^{1}$, Md. Abdul Ahad ${ }^{2 *}$, Most. Rubiya Khatun ${ }^{3}$ and M. A. Hossain ${ }^{4}$
}

${ }^{1}$ MS Student, Department of Entomology. Faculty of Agriculture Hajee Mohammad Danesh Science and Technology University, Dinajpur5200, Bangladesh. E-mail: fatem.zohora@gmail.com

${ }^{2}$ Professor, Dept. of Entomology, Faculty of Agriculture Hajee Mohammad Danesh Science and Technology University, Dinajpur-5200, Bangladesh. E-mail: maahadhstu@gmail.com

${ }^{3}$ MS Student, Department of Fisheries University of Rajshahi, Bangladesh. E-mail: rubiyakhatun259@gmail.com

${ }^{4}$ Professor, Department of Entomology, Faculty of Agriculture Hajee Mohammad Danesh Science and Technology University, Dinajpur5200, Bangladesh. E-mail: alamgirhstu@gmail.com

\section{Article Info}

Volume 1, Issue 2, May 2021

Received : 15 December 2020

Accepted : 19 April 2021

Published : 05 May 2021

doi: 10.51483/IJAGST.1.2.2021.40-50

\section{Introduction}

\begin{abstract}
The experiments were conducted in the laboratory of the Department of Entomology and Department of Agricultural Chemistry, Hajee Mohammad Danesh Science and Technology University (HSTU), Dinajpur during May-December 2017 to evaluate the toxicity of five medicinal plant extracts (water hyacinth Eichhornia crassipes, swamp smartweed Polygonum coccineum, ariach Cassia tora, wild capsicum Croton bonplandianum and hill glory bower Clerodendrum viscosum) against maize weevil, Sitophilus zeamais (Mots.) on stored maize. The wild capsicum extract provided the highest average mortality $(93.33 \pm 3.33)$, following the hill glory bower $(86.67 \pm 3.33)$ and swamp smartweed $(86.67 \pm 3.33)$ at $3 \%$ concentration. But it was zero in control. The average numbers of lowest numbers of adult emergence among the five weed extracts were found in wild capsicum $(3.00 \pm 0.39)$ following Swamp smartweed $(5.11 \pm 0.95)$ at $3 \%$ concentration; whereas, in control it was $(54.00 \pm 1.15)$. The lowest percent of seed damage were found in wild capsicum $(3.00 \pm 0.38 \%)$ following Swamp smartweed $(4.22 \pm 0.58)$. But in control, it was $44.00 \pm 1.15$. Repellency class of different plant extracts at different concentration level varied between I to IV. But the hill glory bower at $3.0 \%$ showed statistically best as it showed the highest repellency rate was $66.0 \pm 5.31 \%$ and the group were IV. However, the toxicity order was wild capsicum $>$ swamp smartweed $>$ hill glory bower $>$ water hyacinth $>$, ariach.
\end{abstract}

Keywords: Toxicity, Medicinal plant, Extracts, Sitophilus zeamais (Mots.)

(C) 2021 International Journal of Agricultural Sciences and Technology. This is an open access article under the CC BY license (https://creativecommons.org/licenses/by/4.0/), which permits unrestricted use, distribution, and reproduction in any medium, provided you give appropriate credit to the original author(s) and the source, provide a link to the Creative Commons license, and indicate if changes were made.

Among the foods of human being the stored grains are main food (Padin et al., 2002). But stored product insect caused post harvest losses up to $9 \%$ in developed countries to $20 \%$ over more in developing countries every year (Phillips and Throne, 2010). Storage loss is one of the major problems in developing countries like Bangladesh as well as all over the world. In Bangladesh, the annual grain loss cost as over taka 100 crores (Alam, 1971). It is also reported that more than $70 \%$ of cereal production is stored in farms level in developing countries (Kavita, 2004). The infestation of pests creates a serious problem in grain stocking and its derived industry (Perez et al., 2004).

Several species of insects may infest the grain in storage. There are over 200 major species of insects and mites infesting important crops and stored products (Das, 1998). However, the principal pests of stored grains that causes

\footnotetext{
* Corresponding author: Md. Abdul Ahad, Department of Entomology, Faculty of Agriculture, Hajee Mohammad Danesh Science and Technology University, Dinajpur 5200, Bangladesh. E-mail: maahadhstu@gmail.com
} 
damages by the adult and larva stage of the beetles and moths. There is a continuous need to protect the stored products against deterioration, especially loss of quality and weight during storage. Quantitative and qualitative losses of stored products may result from the feeding by insects, mites, birds, rodents and or from the development of microorganisms all of which are influenced by environmental conditions (Mohale et al., 2010).

Maize (Zea mays L: Gramineae) is a major staple crop for many smallholder farmers over the world. Human maize consumption has an increasing trend due to global population growth and its alternative uses that include; animal feed, fiber, and ethanol production. The demand for maize as feed ingredient is growing fast in Bangladesh. It has been observed that maize production is highly concentrated especially in Dinajpur, Rangpur and Bogra districts (Quasem, 1999). According to Kearney (2010), maize consumption has been increasing and it will reach its peak by 2050 due to industrial countries and as feedstock for biofuels. Maize, being cheaper than other cereals such as rice and wheat, is used as a commodity for food aid in developing countries. However, maize weevil, Sitophilus zeamais (Motsch.) is one of the most serious cosmopolitan pest of stored cereal grain, especially of maize (Zea mays L.), in tropical and subtropical regions (Throne, 1994). In stored maize, heavy infestation of this pest may cause weight losses of as much as 30 40\% (Casey, 1994).

Presently, chemical control is the main emphasis to control this weevil. Synthetic chemical insecticides and fumigants have been applied to control maize weevil in store (Udo, 2005; Abebe et al., 2009; Pereira et al., 2009; Nukenine, 2010). But chemical control of insect pests in storage has serious drawbacks (Sahayaraj, 1994; Khanam et al., 1990; Haque and Hussain, 1993). However, the use of insecticides to control of maize weevil is being threatened by development of maize weevil resistance (Fragoso et al., 2005; Pereira et al., 2009) and the chemical products are also mostly beyond the reach of smallholder farmers (Dhliwayo and Pixley, 2003). To prevail over these problems, alternatives to chemical pesticides for controlling insect pest of storage are necessary. Plant based botanical pesticides can be effective and safe, which are locally available, less hazardous with low toxicity. In addition, plant-based pesticides are renewable in nature and cheaper (Heyde et al., 1983). Moreover plant-derived pesticides can be transferred into practical applications in natural crop protection, which can help the small-scale farmers (Binggeli, 1999). Many botanical extracts contain various types of bioactive ingredients and chemicals which are toxic to stored product insects including S. zeamais. However, there are many research work done on the evaluation of different indigenous plant extracts against stored product pest (Pandey and Brave, 2011 and Arya and Tiwari, 2013). Under these circumstances, an investigation was undertaken to determine the toxicity, repellency and residual effects of leaf extracts of some weed plants such as (i) water hyacinth (Eichhornia crassipes), (ii) swamp smartweed (Polygonum coccineum), (iii) ariach (Cassia tora), (iv) wild capsicum (Croton bonplandianum), and (v) hill glory bower (Clerodendrum viscosum) against $S$. zeamais Motsch. These weed plant are valueless, create disturb to crop plant, less toxicant to the mammals and available to farmers in any part of Bangladesh. So, it is a cheapest method of pest management. Beside weed extracts, an insecticide has been used in this experiment to evaluate its toxicity level on maize weevil. The use of synthetic chemicals as a method of controlling pests is effective yet expensive, dangerous to human health and may create other problems in post harvest industry. So, the specific objectives of the present research works to evaluate the toxicity weed extracts through the direct toxic effect and residual effect by (a) adult emergence test, (b) seed damage test and, (c) the repellency test against maize weevil, $S$. zeamais Motsch.

\section{Materials and methods}

The experiments were conducted in the laboratory of the Department of Entomology and Department of Agricultural Chemistry, Hajee Mohammad Danesh Science and Technology University (HSTU), Dinajpur, Bangladesh from May to

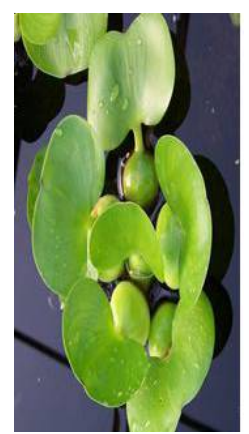

E. crassipes

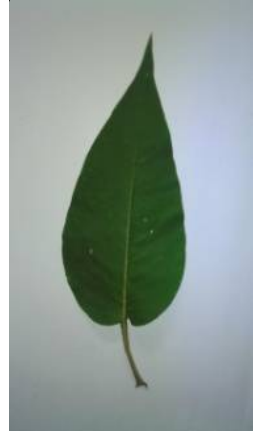

P. coccineum

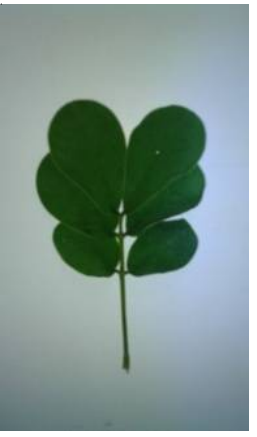

C. tora

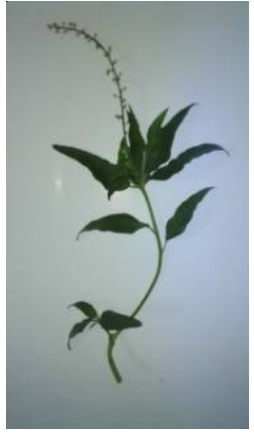

C. bonplandianum

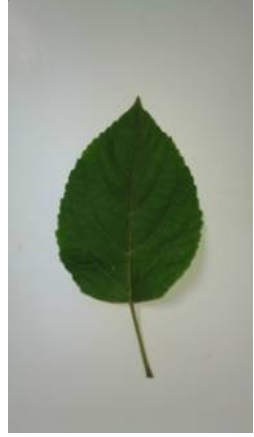

C. viscosum 
December 2017. Insect cultures were maintained in the laboratory at room temperature $\left(30 \pm 2{ }^{\circ} \mathrm{C}\right.$ and with $\left.70 \pm 5 \% \mathrm{RH}\right)$ during the experiments. Leaves of water hyacinth (Eichhornia crassipes), swamp smartweed (Polygonum coccineum), ariach (Cassia tora), wild capsicum (Croton bonplandianum) and bhat (Clerodendrum viscosum) were collected from HSTU Campus. These collected materials were washed in running tap water and then air-dried. Finally, the dried plant materials were powdered by the Mortar.

\section{Preparation of weed extracts}

The leaf powder of $100 \mathrm{~g}$ of each was taken separately in 1.5 liter separated funnel and $130 \mathrm{ml}$-hexane were added and kept for $72 \mathrm{~h}$ with interval of shaking. After $72 \mathrm{~h}$ it was then filtered by Whatman paper No.1 (diameter 40). Then the aqueous extracts were collected in beakers.

\section{Isolation of crude extracts}

After collecting the aqueous extracts into the beaker, the solvents were evaporated by using thin film rotary evaporator under reduced pressure. The condensed crude extracts were then preserved in tightly corked vials and stored in a refrigerator at $4{ }^{\circ} \mathrm{C}$ for further investigation.

\section{Preparation of doses}

The crude extracts were weighted in the electronic balance and dissolved in hexane solvent for making different concentrations $(0.5,1.0,2.0$ and $3.0 \% \mathrm{w} / \mathrm{v})$ of weed extracts and the chemical insecticide at different concentrations $(0.01$, 0.1 and $0.2 \% \mathrm{w} / \mathrm{v}$ ) were prepared along with control (Plate 4 ). Prior to conducting the study, a pilot experiment was done to obtain the appropriate dose.

\subsection{Rearing of test insects and maintenance}

The maize weevil, S. zeamais was used for the present experiments. Small populations of weevils were obtained from the entomology laboratory stock. They were reared in the laboratory at room temperature $\left(30 \pm 2{ }^{\circ} \mathrm{C}\right.$ and with $\left.70 \pm 5 \% \mathrm{RH}\right)$ on maize seeds in a $\operatorname{Jar}(28 \mathrm{~cm} \times 13 \mathrm{~cm})$. Initially, 50 pairs of 1-2 day-old adults were placed in a jar containing maize seeds. The jar was sealed with net cloth and a maximum of seven days were allowed for mating and oviposition. Then parent stocks were removed and maize seeds containing eggs were transferred to fresh maize seeds in another jar and again covered with pieces of a net cloth fastened with rubber bands to prevent the contamination and escape of in-sects. The subsequent progenies of the weevils were used for all the experiments.

\subsection{Direct toxicity test}

The residual film method describes by Busvine (1971) was used to toxicity test of different weed extracts against the adult of maize weevil. Different concentrations $(0.5,1.0,2.0$ and $3.0 \% \mathrm{w} / \mathrm{v})$ of weed extracts were made and $1 \mathrm{ml}$ liquid of each dose was dropped separately on the petridishes $(60 \mathrm{~mm})$ with the help of pipette. Then the plant extracts were covered uniformly to the whole area of the petri dishes internally. The petri dishes were then kept open for sometimes to evaporate the solvent fully. Two days old 10 adult weevils from stock culture were released in each petri dish. The control petri dishes were treated with n-hexane solvent only. Three replications were made for each concentration of plant extracts including control treatment. The Petri-dishes were then kept without food. Insect mortality was recorded at 24, 48, and 72 hours after treatment (HAT). The percentage of mortality was corrected using Abbott's formula (Abbott, 1987).

$$
P=\frac{p^{\prime}-C}{100-C} \times 100
$$

where, $\quad P=$ Percentage of corrected mortality

$P^{\prime}=$ Observed mortality $(\%)$

$C=$ Mortality $(\%)$ at control.

\subsection{Residual toxicity effect}

The weed extracts were mixed with maize seed at the rate of $0.5 \%, 1 \%, 2 \%$ and $3 \%(\mathrm{w} / \mathrm{v})$. The treated maize seeds were air dried for $20 \mathrm{~min}$ and then put into separate plastic pots $\left(6 \times 7 \mathrm{~cm}^{2}\right)$, so that each pot contained 30 gm of maize seeds. Fiveday-old weevils of 5 pairs were released into the plastic pot. After seven days, dead and alive weevils were removed from each pot and kept the pots undisturbed in the laboratory for the emergence of new adult weevils. 


\subsection{Adult emergence inhibition rate}

The maize weevils were started to emerge after 36-40 days of egg laying. The emerged weevils were counted and removed after 40, 47, and 54 days after the experiment set up. The adult emergence rate was recorded and the inhibition rate $(I R \%)$ was calculated by using the following formula as stated by Talukder and Howse (1993).

$$
\operatorname{IR}(\%)=C n-T n / C n \times 100
$$

where, $C n=$ Number of insects in control plastic pot.

$T n=$ Number of insects in treated plastic pot.

\subsection{Seed damage inhibition rate}

The seed was taken out from the pot to determine the hole(s) on each seed carefully. Seeds containing hole(s) were considered as damaged seeds. The numbers of damaged seeds were counted from the random sample of 100 seeds at the end of the experiment and were recorded for each replication. Then inhibition rate $(D I \%)$ was calculated by using the following formula by Talukder and Howse (1993).

$$
D I(\%)=C n-T n / C n \times 100
$$

where, $C n=$ Number of damaged seeds in control plastic pot.

$T n=$ Number of damaged seeds in treated plastic pot.

\subsection{Repellency test}

The repellency test was conducted according to the method of Talukder and Howse (1993). For this test, respective doses of tested plants extracts $(0.5,1.0,2.0$ and $3.0 \% \mathrm{w} / \mathrm{v}$ extract and $0.01,0.1$ were prepared. The filter paper (Whatman no. 1) was cut into two half, and $1 \mathrm{ml}$ solution of each concentration was applied to one half uniformly with the help of micropipette. The treated and control filter papers then air dried for $20 \mathrm{~min}$ to evaporate the solvent completely. With the help of a pipette, $1.0 \mathrm{ml}$ solutions of each plant extract were applied to one half of the petri dish $(90 \mathrm{~mm})$. The treated half was then air-dried and was attached with the untreated half. Ten weevils of five days old were released at the centre of each petri dish and a cover was placed on the petri dish. There were three replications for each plant extract and each dose. Then the insects present on each portion were counted at hourly intervals up to fifth hour. The data were expressed as percentage repulsion $(P R)$ by the following formula:

$$
P R(\%)=(N C-50) \times 2
$$

where, $N C=$ The percentage of insects present in the control half.

Positive $(+)$ values expressed repellency and negative (-) values attractions. Data (PR \%) was analyzed using Analysis of Variance (ANOVA). The average values were then categorized according to the following scale (McDonald et al., 1970).

\begin{tabular}{|l|c|}
\hline Class & Repellency (\%) \\
\hline 0 & $0>0.01$ to 0.1 \\
\hline I & 0.1 to 20 \\
\hline II & 20.1 to 40 \\
\hline III & 40.1 to 60 \\
\hline IV & 60.1 to 80 \\
\hline V & 80.1 to 100 \\
\hline
\end{tabular}




\section{Statistical analyses}

The data obtained from the experiments were statistically analyzed by MSTAT and SPSS computer program following Completely Randomized Design (CRD) method. The significance of the mean differences was tested by DMRT. The observed mortality was also subjected to probit analysis.

\section{Results and discussion}

The experiment was conducted to find out the acute and lethal effect of five indigenous weed extracts (water hyacinth (Eichhornia crassipes), swamp smartweed (Polygonum coccineum), ariach (Cassia tora), wild capsicum (Croton bonplandianum) and bhat (Clerodendrum viscosum) were against maize weevil (S. zeamais). The outcomes of the experiment are presented and discussed under the following sub-headings.

\subsection{Direct toxicity effect of different plant extracts against the adult of $S$. zeamais}

The direct toxicity effect based \% mortality of different plant extracts at doses different time intervals against the adult S. zeamais are presented in the Table 1. Mortality of maize weevil also differed significantly among all the concentrations

\begin{tabular}{|c|c|c|c|c|c|}
\hline \multirow{2}{*}{ Plant extracts } & \multirow{2}{*}{ Doses $(\%)$} & \multicolumn{3}{|c|}{ Insect mortality $(\%)$ at different time intervals } & \multirow[t]{2}{*}{ Average mortality $(\%)$} \\
\hline & & 24 HAT & 48 HАТ & 72 HАT & \\
\hline \multirow[t]{4}{*}{ Water hyacinth } & 0.5 & $3.33 \pm 3.33 \mathrm{gh}$ & $6.67 \pm 3.33 \mathrm{gh}$ & $16.67 \pm 3.33 \mathrm{~g}$ & $8.867 \pm 2.94 \mathrm{gh}$ \\
\hline & 1.0 & $6.667 \pm 3.33 \mathrm{fgh}$ & $13.33 \pm 3.33 \mathrm{fgh}$ & $33.33 \pm 3.33$ ef & $17.77 \pm 2.23 \mathrm{~g}$ \\
\hline & 2.0 & $13.33 \pm 6.67 \mathrm{efg}$ & $40.00 \pm 5.773 \mathrm{de}$ & $60.00 \pm 0.00 \mathrm{~d}$ & $37.77 \pm 3.99 \mathrm{de}$ \\
\hline & 3.0 & $26.67 \pm 3.33 \mathrm{bcd}$ & $66.67 \pm 3.33 \mathrm{bc}$ & $80.00 \pm 0.00 \mathrm{bc}$ & $57.77 \pm 2.23 \mathrm{~b}$ \\
\hline \multirow[t]{4}{*}{ Swamp smartweed } & 0.5 & $3.333 \pm 3.33 \mathrm{gh}$ & $3.33 \pm 3.33 \mathrm{~h}$ & $23.33 \pm 3.33 \mathrm{fg}$ & $10.00 \pm 1.91 \mathrm{gh}$ \\
\hline & 1.0 & $3.33 \pm 3.33 \mathrm{gh}$ & $23.33 \pm 3.33$ efg & $60.00 \pm 5.77 \mathrm{~d}$ & $28.90 \pm 2.20$ ef \\
\hline & 2.0 & $10.00 \pm 5.77 \mathrm{fgh}$ & $30.00 \pm 10.00 \mathrm{ef}$ & $80.00 \pm 5.77 b c$ & $40.00 \pm 5.77 \mathrm{~cd}$ \\
\hline & 3.0 & $33.33 \pm 3.33 \mathrm{bc}$ & $53.33 \pm 3.33 \mathrm{~cd}$ & $86.67 \pm 3.33 \mathrm{ab}$ & $57.80 \pm 1.10 \mathrm{~b}$ \\
\hline \multirow[t]{4}{*}{ Ariach } & 0.5 & $3.33 \pm 3.33 \mathrm{gh}$ & $3.33 \pm 3.33 \mathrm{~h}$ & $20.00 \pm 5.77 \mathrm{~g}$ & $8.90 \pm 4.00 \mathrm{gh}$ \\
\hline & 1.0 & $3.33 \pm 3.33 \mathrm{gh}$ & $16.67 \pm 3.33 \mathrm{fgh}$ & $40.00 \pm 3.33 \mathrm{e}$ & $20.03 \pm 5.77 \mathrm{fg}$ \\
\hline & 2.0 & $6.67 \pm 6.67 \mathrm{fgh}$ & $36.67 \pm 17.64 \mathrm{de}$ & $80.00 \pm 5.77 b c$ & $41.13 \pm 9.87 \mathrm{~cd}$ \\
\hline & 3.0 & $16.67 \pm 3.33 \mathrm{def}$ & $40.00 \pm 5.77 \mathrm{de}$ & $80.00 \pm 5.77 b c$ & $45.53 \pm 3.99 \mathrm{~cd}$ \\
\hline \multirow[t]{4}{*}{ Wild capsicum } & 0.5 & $23.33 \pm 3.33 \mathrm{cde}$ & $56.67 \pm 8.82 \mathrm{bc}$ & $70.00 \pm 5.77 \mathrm{~cd}$ & $50.00 \pm 5.09 \mathrm{bc}$ \\
\hline & 1.0 & $36.67 \pm 6.67 \mathrm{~b}$ & $60.00 \pm 5.77 \mathrm{bc}$ & $76.67 \pm 3.33 \mathrm{bc}$ & $57.77 \pm 3.99 \mathrm{~b}$ \\
\hline & 2.0 & $66.67 \pm 3.33 \mathrm{a}$ & $73.33 \pm 3.33 \mathrm{ab}$ & $86.67 \pm 3.33 \mathrm{ab}$ & $75.53 \pm 2.23 \mathrm{a}$ \\
\hline & 3.0 & $73.33 \pm 3.33 \mathrm{a}$ & $83.33 \pm 3.33 \mathrm{a}$ & $93.33 \pm 3.33 \mathrm{a}$ & $83.33 \pm 1.93 \mathrm{a}$ \\
\hline \multirow[t]{4}{*}{ Hill glory bower } & 0.5 & $3.33 \pm 2.94 \mathrm{gh}$ & $3.33 \pm 3.33 \mathrm{~h}$ & $23.33 \pm 3.33 \mathrm{fg}$ & $10.03 \pm 3.33 \mathrm{gh}$ \\
\hline & 1.0 & $3.33 \pm 3.33 \mathrm{gh}$ & $6.67 \pm 3.33 \mathrm{gh}$ & $36.67 \pm 3.33 \mathrm{e}$ & $15.57 \pm 3.33 \mathrm{~g}$ \\
\hline & 2.0 & $10.00 \pm 5.77 \mathrm{fgh}$ & $23.33 \pm 3.33 \mathrm{efg}$ & $76.67 \pm 3.33 \mathrm{bc}$ & $36.67 \pm 3.33 \mathrm{de}$ \\
\hline & 3.0 & $16.67 \pm 3.33 \mathrm{def}$ & $30.00 \pm 5.77 \mathrm{ef}$ & $86.67 \pm 3.33 \mathrm{ab}$ & $44.47 \pm 3.99 \mathrm{~cd}$ \\
\hline
\end{tabular}




\begin{tabular}{|c|c|c|c|c|c|}
\hline \multirow{2}{*}{ Plant extracts } & \multirow{2}{*}{ Doses $(\%)$} & \multicolumn{3}{|c|}{ Insect mortality $(\%)$ at different time intervals } & \multirow[t]{2}{*}{ Average mortality $(\%)$} \\
\hline & & 24 HAT & 48 HAT & 72 HAT & \\
\hline Control & & $0.00 \pm 0.00 \mathrm{~h}$ & $0.00 \pm 0.00 \mathrm{~h}$ & $0.00 \pm 0.00 \quad \mathrm{~h}$ & $0.00 \pm 0.00$ \\
\hline LSD & & 10.88 & 15.73 & 10.71 & 10.10 \\
\hline $\mathrm{CV} \%$ & & 45.64 & 35.79 & 13.50 & 20.58 \\
\hline
\end{tabular}

level at different time intervals. However, the average mortality percentage differed statistically among all the plant extracts. Mortality percentages were increased proportionally with the increased time intervals. The wild capsicum extract provided the highest average mortality $(93.33 \pm 3.33)$, following the hill glory bower $(86.67 \pm 3.33)$ and swamp smartweed $(86.67 \pm 3.33)$ at $3 \%$ concentration at $72 \mathrm{~h}$. But mortality was zero. in the control, On the basis of insect mortality the order of the toxic effect of five tested weed extracts against maize weevil were found of wild capsicum $>$ swamp smartweed $>$ hill glory bower $>$ water hyacinth $>$ ariach.

\subsection{Residual effects of weed extracts against maize weevil}

(a) On the basis of inhibition of adult emergence: The result of residual toxic effects based on the average numbers of adult emergence five weed extract (of water hyacinth, swamp smartweed, ariach, wild capsicum and hill glory bower on S. zeamais at different days after treatment (DAT) are presented in Table 2 . The average numbers of adult emergence

Table 2: Residual toxicity on adult emergence and inhibition against $S$. zeamais treated with weed extracts and doses at different DAT

\begin{tabular}{|c|c|c|c|c|c|c|}
\hline \multirow{2}{*}{ Plant extracts } & \multirow{2}{*}{ Doses $(\%)$} & \multicolumn{3}{|c|}{ Mean number of adult emergence (DAT) } & \multirow{2}{*}{ Average } & \multirow{2}{*}{$\operatorname{IR}(\%)$} \\
\hline & & 40 DAT & 47 DAT & 54 DAT & & \\
\hline \multirow[t]{4}{*}{ Water hyacinth } & 0.5 & $15.00 \pm 1.15 \mathrm{c}$ & $24.67 \pm 1.45 \mathrm{c}$ & $33.67 \pm 1.20 \mathrm{c}$ & $24.45 \pm 0.399 \mathrm{c}$ & $54.73 \pm 0.74 \mathrm{~g}$ \\
\hline & 1.0 & $11.67 \pm 1.20 \mathrm{de}$ & $16.67 \pm 0.88 \mathrm{f}$ & $28.00 \pm 1.53 \mathrm{ef}$ & $18.78 \pm 0.99 \mathrm{e}$ & $65.22 \pm 1.83 \mathrm{e}$ \\
\hline & 2.0 & $7.00 \pm 1.15 \mathrm{~g}$ & $12.00 \pm 1.15 \mathrm{ghi}$ & $22.67 \pm 1.45 \mathrm{gh}$ & $13.89 \pm 1.25 \mathrm{fgh}$ & $74.28 \pm 2.31 \mathrm{~cd}$ \\
\hline & 3.0 & $2.33 \pm 0.33 \mathrm{i}$ & $4.67 \pm 0.33 \mathrm{k}$ & $9.00 \pm 0.58 \mathrm{kl}$ & $5.33 \pm 0.33 \mathrm{j}$ & $90.12 \pm 0.62 \mathrm{a}$ \\
\hline \multirow[t]{4}{*}{ Swamp smartweed } & 0.5 & $13.67 \pm 0.88 \mathrm{~cd}$ & $21.00 \pm 0.58 \mathrm{de}$ & $32.67 \pm 1.45 \mathrm{~cd}$ & $22.44 \pm 0.68 \mathrm{c}$ & $58.44 \pm 1.25 \mathrm{~g}$ \\
\hline & 1.0 & $11.33 \pm 0.67 \mathrm{de}$ & $17.67 \pm 0.33 \mathrm{ef}$ & $29.33 \pm 1.20 \mathrm{cde}$ & $19.44 \pm 0.29 \mathrm{de}$ & $63.99 \pm 0.54 \mathrm{ef}$ \\
\hline & 2.0 & $6.00 \pm 0.58 \mathrm{gh}$ & $11.67 \pm 0.88 \mathrm{hi}$ & $19.33 \pm 0.88 \mathrm{hi}$ & $12.33 \pm 0.69 \mathrm{gh}$ & $77.16 \pm 1.28 \mathrm{c}$ \\
\hline & 3.0 & $2.00 \pm 0.58 \mathrm{i}$ & $5.67 \pm 1.20 \mathrm{jk}$ & $7.67 \pm 1.45 \mathrm{kl}$ & $5.11 \pm 0.95 \mathrm{j}$ & $90.53 \pm 1.76$ a \\
\hline \multirow[t]{4}{*}{ Ariach } & 0.5 & $19.33 \pm 0.88 b$ & $31.33 \pm 0.88 b$ & $41.00 \pm 4.04 \mathrm{~b}$ & $30.55 \pm 1.89 \mathrm{~b}$ & $43.42 \pm 3.52 \mathrm{~h}$ \\
\hline & 1.0 & $12.00 \pm 0.58 \mathrm{de}$ & $17.67 \pm 1.45$ ef & $28.33 \pm 1.45 \mathrm{de}$ & $19.33 \pm 1.07 \mathrm{de} 6$ & $64.19 \pm 1.98$ ef \\
\hline & 2.0 & $7.67 \pm 1.45 \mathrm{fg}$ & $15.00 \pm 1.53 \mathrm{fgh}$ & $20.67 \pm 1.76 \mathrm{gh}$ & $14.45 \pm 1.35 \mathrm{fgh}$ & $73.25 \pm 2.51 \mathrm{~cd}$ \\
\hline & 3.0 & $7.00 \pm 0.58 \mathrm{~g}$ & $9.00 \pm 1.15 \mathrm{ij}$ & $11.67 \pm 2.33 \mathrm{jk}$ & $9.223 \pm 1.35 \mathrm{i}$ & $82.92 \pm 2.51 \mathrm{~b}$ \\
\hline \multirow[t]{2}{*}{ Wild capsicum } & 0.5 & $14.00 \pm 1.15 \mathrm{~cd}$ & $18.33 \pm 1.20 \mathrm{ef}$ & $23.67 \pm 0.67 \mathrm{fgh}$ & $18.67 \pm 0.84 \mathrm{e}$ & $65.43 \pm 1.56 \mathrm{e}$ \\
\hline & 1.0 & $12.00 \pm 0.58 \mathrm{de}$ & $15.33 \pm 0.88 \mathrm{fg}$ & $19.67 \pm 0.88 \mathrm{hi}$ & $15.67 \pm 0.58 \mathrm{f}$ & $70.98 \pm 1.07 \mathrm{~d}$ \\
\hline
\end{tabular}




\begin{tabular}{|c|c|c|c|c|c|c|}
\hline \multirow{2}{*}{ Plant extracts } & \multirow{2}{*}{ Doses $(\%)$} & \multicolumn{3}{|c|}{ Mean number of adult emergence (DAT) } & \multirow{2}{*}{ Average } & \multirow{2}{*}{$\operatorname{IR}(\%)$} \\
\hline & & 40 DAT & 47 DAT & 54 DAT & & \\
\hline & 2.0 & $6.67 \pm 0.88 \mathrm{~g}$ & $9.00 \pm 0.58 \mathrm{ij}$ & $11.00 \pm 0.58 \mathrm{jk}$ & $8.89 \pm 0.40 \mathrm{i}$ & $83.53 \pm 0.74 \mathrm{~b}$ \\
\hline & 3.0 & $1.00 \pm 0.00 \mathrm{i}$ & $2.667 \pm 0.33 \mathrm{k}$ & $5.33 \pm 0.881$ & $3.00 \pm 0.39 \mathrm{j}$ & $94.44 \pm 0.72 \mathrm{a}$ \\
\hline \multirow[t]{5}{*}{ Hill glory bower } & 0.5 & $18.00 \pm 0.58 \mathrm{~b}$ & $22.67 \pm 1.45 \mathrm{~cd}$ & $25.00 \pm 1.15 \mathrm{efg}$ & $21.89 \pm 1.06 \mathrm{~cd}$ & $59.46 \pm 1.96 \mathrm{fg}$ \\
\hline & 1.0 & $10.33 \pm 0.88$ ef & $16.00 \pm 1.00 \mathrm{f}$ & $19.67 \pm 0.88 \mathrm{hi}$ & $15.33 \pm 0.88 \mathrm{fg}$ & $71.60 \pm 1.63 \mathrm{~d}$ \\
\hline & 2.0 & $8.33 \pm 0.88 \mathrm{fg}$ & $11.33 \pm 1.20 \mathrm{i}$ & $15.33 \pm 0.67 \mathrm{ij}$ & $11.67 \pm 0.88 \mathrm{hi}$ & $78.39 \pm 1.63 \mathrm{bc}$ \\
\hline & 3.0 & $3.67 \pm 1.20 \mathrm{hi}$ & $5.67 \pm 0.67 \mathrm{jk}$ & $7.67 \pm 0.33 \mathrm{kl}$ & $5.67 \pm 0.67 \mathrm{j}$ & $89.50 \pm 1.24 \mathrm{a}$ \\
\hline & Control & $49.67 \pm 1.20$ a & $53.67 \pm 1.45 \mathrm{a}$ & $58.67 \pm 1.33$ a & $54.00 \pm 1.15 \mathrm{a}$ & - \\
\hline LSD & & 2.70 & 3.20 & 4.16 & 2.80 & 4.97 \\
\hline CV \% & & 9.43 & 8.78 & 8.99 & 7.54 & 4.15 \\
\hline \multicolumn{7}{|c|}{$\begin{array}{l}\text { Note: DAT = Days After Treatment; Within column values followed by different letter(s) are significantly different by DMRT at } \\
5 \% \text { level of probability. }\end{array}$} \\
\hline
\end{tabular}

among all the weed extracts in all level of concentrations were statistically significant. However, the lowest numbers of adult emergence among the five weed extract was found in wild capsicum (3.00 \pm 0.39$)$ following Swamp smartweed (5.11 $\pm 0.95)$, Water hyacinth $(5.33 \pm 0.33 \mathrm{j})$, and Hill glory bower $(5.67 \pm 0.67)$, ariach $(9.223 \pm 1.35)$, respectively; whereas in control it was $54.00 \pm 1.15$ (Table 2). The lowest numbers of adult emergence means the highest toxicity. So, those extract were best respectively for the control of maize weevil, $S$. zeamais. On the basis of inhibition of adult emergence the order of the toxic effect of five tested weed extracts against maize weevil were found of wild capsicum $>$ swamp smartweed $>$ water hyacinth $>$ hill glory bower.

The results of present study are more or less similar to that of Bosa (2014). From the maize-amaranth experiment, he concluded that blending maize with amaranth during storage reduced maize weevil population growth by $46 \%$ compared to storing maize alone.

\section{(a) On the basis of seed damage and inhibition against $S$. zeamais treated with different weed extracts}

The result of $\%$ seed damage of water hyacinth, swamp smartweed, ariach, wild capsicum and hill glory bower plant extracts on S. zeamais at different DAT are presented in Table 5. The average the percentage of seed damage inhibition among the entire weed extracts in all level the concentrations were statistically significant. However, the lowest percent of damage was found in wild capsicum $(3.00 \pm 0.38 \%)$ following Swamp smartweed $(4.22 \pm 0.58)$, Water hyacinth $(4.89 \pm$ 0.11 ), and next Hill glory bower ( $4.89 \pm 0.11)$, ariach $(8.22 \pm 0.78)$. But in control it was $44.00 \pm 1.15$ (Table 3 ). The lowest $\%$ seed damage means the highest toxicity. So, those extract were preformed best for check the damage of seed. However, on the basis of $\%$ seed damage the order of the toxic effect of five tested weed extracts against maize weevil were found of wild capsicum $>$ swamp smartweed $>$ water hyacinth $>$ hill glory bower $>$ ariach.

Table 3: Residual toxicity based on seed damage \% against $S$. zeamais treated with weed extracts and doses at different DAT

\begin{tabular}{|c|c|c|c|c|c|c|}
\hline \multirow{2}{*}{ Plant extracts } & \multirow{2}{*}{ Doses $(\%)$} & \multicolumn{3}{|c|}{ Mean number of seed damage (DAT) } & \multirow{2}{*}{ Average } & \multirow{2}{*}{$\operatorname{DI}(\%)$} \\
\hline & & 40 DAT & 47 DAT & 54 DAT & & \\
\hline \multirow[t]{2}{*}{ Water hyacinth } & 0.5 & $12.33 \pm 0.88 \mathrm{~cd}$ & $18.67 \pm 1.33 \mathrm{c}$ & $24.67 \pm 1.20 \mathrm{c}$ & $18.55 \pm 0.39 \mathrm{c}$ & $57.83 \pm 0.91 \mathrm{i}$ \\
\hline & 1.0 & $10.33 \pm 0.88 \mathrm{def}$ & $13.33 \pm 0.67 \mathrm{fg}$ & $18.67 \pm 0.67 \mathrm{defg}$ & $14.11 \pm 0.62 \mathrm{e}$ & $67.93 \pm 1.40 \mathrm{fg}$ \\
\hline
\end{tabular}


Table 3 (Cont.)

\begin{tabular}{|c|c|c|c|c|c|c|}
\hline \multirow{2}{*}{ Plant extracts } & \multirow{2}{*}{ Doses $(\%)$} & \multicolumn{3}{|c|}{ Mean number of seed damage (DAT) } & \multirow{2}{*}{ Average } & \multirow{2}{*}{$\operatorname{DI}(\%)$} \\
\hline & & 40 DAT & 47 DAT & 54 DAT & & \\
\hline & 2.0 & $6.67 \pm 0.88 \mathrm{hi}$ & $9.00 \pm 0.58 \mathrm{hi}$ & $15.00 \pm 0.58 \mathrm{ghi}$ & $10.22 \pm 0.67 \mathrm{f}$ & $76.77 \pm 1.53 \mathrm{e}$ \\
\hline & 3.0 & $2.33 \pm 0.33 \mathrm{kl}$ & $4.33 \pm 0.33 \mathrm{kl}$ & $8.00 \pm 0.58 \mathrm{klm}$ & $4.89 \pm 0.11 \mathrm{ij}$ & $88.88 \pm 0.25 b$ \\
\hline \multirow[t]{4}{*}{ Swamp smartweed } & 0.5 & $11.67 \pm 0.88 \mathrm{de}$ & $17.00 \pm 0.58 \mathrm{~cd}$ & $21.67 \pm 0.88 \mathrm{cde}$ & $16.78 \pm 0.48 \mathrm{~cd}$ & $61.86 \pm 1.10 \mathrm{hi}$ \\
\hline & 1.0 & $9.00 \pm 0.58 \mathrm{fg}$ & $13.33 \pm 0.67 \mathrm{fg}$ & $18.00 \pm 0.58 \mathrm{efgh}$ & $13.44 \pm 0.11 \mathrm{e}$ & $69.44 \pm 0.26 \mathrm{fg}$ \\
\hline & 2.0 & $5.00 \pm 0.58 \mathrm{ij}$ & $9.67 \pm 0.88 \mathrm{hi}$ & $13.00 \pm 0.58 \mathrm{ij}$ & $9.22 \pm 0.62 \mathrm{fg}$ & $79.03 \pm 1.41 \mathrm{cde}$ \\
\hline & 3.0 & $1.67 \pm 0.33 \mathrm{kl}$ & $4.67 \pm 0.88 \mathrm{kl}$ & $6.33 \pm 0.88 \mathrm{~lm}$ & $4.22 \pm 0.58 \mathrm{ij}$ & $90.40 \pm 1.34 \mathrm{ab}$ \\
\hline \multirow[t]{4}{*}{ Ariach } & 0.5 & $15.33 \pm 0.88 \mathrm{~b}$ & $26.00 \pm 0.58 \mathrm{~b}$ & $35.67 \pm 2.18 \mathrm{~b}$ & $25.67 \pm 1.17 b$ & $42.49 \pm 1.84 \mathrm{j}$ \\
\hline & 1.0 & $11.67 \pm 0.33 \mathrm{de}$ & $16.33 \pm 0.88 \mathrm{cde}$ & $22.00 \pm 1.15 \mathrm{~cd}$ & $16.67 \pm 0.77 \mathrm{~cd}$ & $62.12 \pm 1.75 \mathrm{hi}$ \\
\hline & 2.0 & $7.67 \pm 1.45 \mathrm{gh}$ & $12.67 \pm 1.20 \mathrm{fg}$ & $17.33 \pm 1.45 \mathrm{fgh}$ & $12.55 \pm 1.18 \mathrm{e}$ & $71.47 \pm 2.67 f$ \\
\hline & 3.0 & $6.33 \pm 0.33 \mathrm{hi}$ & $8.00 \pm 0.58 \mathrm{ij}$ & $10.33 \pm 1.45 \mathrm{jk}$ & $8.22 \pm 0.78 \mathrm{fg}$ & $81.31 \pm 1.77 \mathrm{~cd}$ \\
\hline \multirow[t]{4}{*}{ Wild capsicum } & 0.5 & $11.33 \pm 0.88 \mathrm{de}$ & $15.00 \pm 0.58 \mathrm{def}$ & $18.67 \pm 0.67 \mathrm{defg}$ & $15.00 \pm 0.51 \mathrm{de}$ & $65.90 \pm 1.16 \mathrm{gh}$ \\
\hline & 1.0 & $10.00 \pm 0.58$ ef & $11.67 \pm 0.88 \mathrm{gh}$ & $16.00 \pm 0.58 \mathrm{ghi}$ & $12.56 \pm 0.48 \mathrm{e}$ & $71.46 \pm 1.09 \mathrm{f}$ \\
\hline & 2.0 & $5.33 \pm 0.33 \mathrm{ij}$ & $7.67 \pm 0.33 \mathrm{ij}$ & $9.33 \pm 0.33 \mathrm{kl}$ & $7.47 \pm 0.22 \mathrm{gh}$ & $83.07 \pm 0.51 \mathrm{c}$ \\
\hline & 3.0 & $1.00 \pm 0.001$ & $2.67 \pm 0.331$ & $5.33 \pm 0.88 \mathrm{~m}$ & $3.00 \pm 0.38 \mathrm{j}$ & $93.18 \pm 0.88 \mathrm{a}$ \\
\hline \multirow[t]{5}{*}{ Hill glory bower } & 0.5 & $14.00 \pm 0.58 \mathrm{bc}$ & $18.00 \pm 1.53 \mathrm{c}$ & $20.67 \pm 1.20 \mathrm{def}$ & $17.56 \pm 1.06 \mathrm{c}$ & $60.10 \pm 2.40 \mathrm{i}$ \\
\hline & 1.0 & $10.33 \pm 0.88 \mathrm{def}$ & $14.00 \pm 0.58 \mathrm{efg}$ & $14.67 \pm 0.33 \mathrm{hi}$ & $13.00 \pm 0.51 \mathrm{e}$ & $70.45 \pm 1.16 \mathrm{f}$ \\
\hline & 2.0 & $7.00 \pm 0.58$ ghi & $9.33 \pm 0.33 \mathrm{hi}$ & $13.33 \pm 0.67 \mathrm{ij}$ & $9.89 \pm 0.40 \mathrm{f}$ & $77.52 \pm 0.91 \mathrm{de}$ \\
\hline & 3.0 & $3.33 \pm 0.88 \mathrm{jk}$ & $5.67 \pm 0.67 \mathrm{jk}$ & $7.67 \pm 0.33 \mathrm{klm}$ & $5.57 \pm 0.56 \mathrm{hi}$ & $87.37 \pm 1.26 b$ \\
\hline & Control & $40.67 \pm 0.67 \mathrm{a}$ & $44.00 \pm 1.15 \mathrm{a}$ & $47.33 \pm 1.76 \mathrm{a}$ & $44.00 \pm 1.15 \mathrm{a}$ & - \\
\hline LSD & & 2.031 & 2.48 & 3.34 & 2.21 & 4.05 \\
\hline CV \% & & 8.47 & 8.28 & 9.19 & 7.35 & 3.36 \\
\hline
\end{tabular}

Note: $\mathrm{DAT}=$ Days After Treatment; Within column values followed by different letter(s) are significantly different by DMRT at $5 \%$ level of probability.

\subsection{Repellent effect of different weed extracts against the adult of S. zeamais}

The percent of mean repellent rate ( 1 h, $2 \mathrm{~h}, 3 \mathrm{~h}, 4 \mathrm{~h}$ and $5 \mathrm{~h}$ ) effect of five weed (water hyacinth, swamp smartweed, ariach, wild capsicum and hill glory bower) in $n$-hexane solvent extracts against the adult of $S$. zeamais is presented in Table 4. Data were statistically significant of each treatment $(p<0.05)$. The repellency class of different plant extracts at different concentration level varied between I to IV. Among the five weed extracts tested, the hill glory bower at $3.0 \%$ showed statistically best as it showed the highest repellency rate was $66.0 \pm 5.31 \%$ and group was IV. The next highest repellency group was water hyacinth, swamp smartweed and ariach; the repellency rate was $56.00 \pm 8.00,54.70 \pm 8.1 \%$ and $48 \pm 1.4 \%$, respectively at $3.0 \%$ and the group of those weed extract were III. The rest group was I and II at $1 \%$ and $2 \%$ of all the tested weed plant (Table 4 ). However, on the basis of Repellent effect the order of the toxic effect of five tested weed extracts against maize weevil were found of hill glory bower $>$ water hyacinth $>$, swamp smartweed $>$ wild capsicum $>$ ariach. The study of repellent effect of weed extracts was also agreed by the observation of Waliullah et al. (2014). The repellent activity was done using ethyl alcohol fraction of 
Clerodendrum viscosum. All the extracts (root, leafand stem) showed 100\% repellency (Class V category repellency) in dose no 1 to dose no 5 except stem. The degree of repellency response among the three parts of test insect was significantly differ $(p<0.05)$. About similar results also found by Ahad et al., 2016a and Ahad et al., 2016b.

\begin{tabular}{|c|c|c|c|c|c|c|c|c|}
\hline \multirow{2}{*}{$\begin{array}{l}\text { Plant } \\
\text { extracts }\end{array}$} & \multirow{2}{*}{$\begin{array}{c}\text { Doses } \\
(\%)\end{array}$} & \multicolumn{5}{|c|}{ Repellency rate \% } & \multirow{2}{*}{$\begin{array}{c}\text { \% Mean } \\
\text { repell. }\end{array}$} & \multirow{2}{*}{$\begin{array}{l}\text { Rep. } \\
\text { Cla. }\end{array}$} \\
\hline & & 1 HAT & 2 HAT & 3 HAT & 4 HAT & 5 HAT & & \\
\hline \multirow{4}{*}{$\begin{array}{l}\text { Water } \\
\text { hyacinth }\end{array}$} & 0.5 & $13.33 \pm 6.67 \mathrm{bcd}$ & $13.33 \pm 13.33 \mathrm{~cd}$ & $6.667 \pm 6.67 \mathrm{~d}$ & $20.00 \pm 11.55 \mathrm{cde}$ & $26.67 \pm 6.67 \mathrm{bcd}$ & $16.00 \pm 4.62 \mathrm{fg}$ & I \\
\hline & 1.0 & $13.33 \pm 6.67 \mathrm{bcd}$ & $6.667 \pm 6.67 \mathrm{~d}$ & $40.00 \pm 11.55 \mathrm{abcd}$ & $13.33 \pm 6.67 \mathrm{de}$ & $33.33 \pm 6.67 \mathrm{abcd}$ & $21.33 \pm 1.33 \mathrm{defg}$ & II \\
\hline & 2.0 & $33.33 \pm 6.67 \mathrm{bcd}$ & $13.33 \pm 6.67 \mathrm{~cd}$ & $20.00 \pm 11.55 \mathrm{bcd}$ & $53.33 \pm 6.67 \mathrm{bc}$ & $73.33 \pm 6.67 \mathrm{a}$ & $38.67 \pm 5.82 \mathrm{bcde}$ & II \\
\hline & 3.0 & $33.33 \pm 13.3 \mathrm{bcd}$ & $60.00 \pm 20.00 \mathrm{ab}$ & $53.33 \pm 6.67 \mathrm{ab}$ & $66.67 \pm 13.33 \mathrm{ab}$ & $66.67 \pm 6.67 \mathrm{ab}$ & $56.00 \pm 8.00 \mathrm{ab}$ & III \\
\hline \multirow{4}{*}{$\begin{array}{l}\text { Swamp } \\
\text { smart } \\
\text { weed }\end{array}$} & 0.5 & $6.67 \pm 6.67 \mathrm{~cd}$ & $6.67 \pm 6.67 \mathrm{~d}$ & $6.67 \pm 6.67 \mathrm{~d}$ & $13.33 \pm 6.67 \mathrm{de}$ & $13.33 \pm 6.67 \mathrm{~cd}$ & $9.33 \pm 1.33 \mathrm{~g}$ & I \\
\hline & 1.0 & $6.67 \pm 6.67 \mathrm{~cd}$ & $6.67 \pm 6.67 \mathrm{~d}$ & $13.33 \pm 6.67 \mathrm{~cd}$ & $6.67 \pm 6.67 \mathrm{e}$ & $26.67 \pm 13.33 \mathrm{bcd}$ & $12.00 \pm 2.31 \mathrm{fg}$ & I \\
\hline & 2.0 & $6.67 \pm 6.67 \mathrm{~cd}$ & $33.33 \pm 6.67 \mathrm{abcd}$ & $33.33 \pm 13.33 \mathrm{abcd}$ & $40.00 \pm 0.000 \mathrm{bcde}$ & $33.33 \pm 24.04 \mathrm{abcd}$ & $29.33 \pm 4.81 \mathrm{cdefg}$ & II \\
\hline & 3.0 & $40.00 \pm 11.55 \mathrm{abcd}$ & $66.67 \pm 6.67 \mathrm{a}$ & $53.33 \pm 17.64 \mathrm{ab}$ & $46.67 \pm 6.67 \mathrm{bcd}$ & $66.67 \pm 6.67 \mathrm{ab}$ & $54.67 \pm 8.11 \mathrm{ab}$ & III \\
\hline \multirow[t]{4}{*}{ Ariach } & 0.5 & $13.33 \pm 6.67 \mathrm{bcd}$ & $6.67 \pm 6.67 \mathrm{~d}$ & $40.00 \pm 11.55 \mathrm{abcd}$ & $26.67 \pm 6.67 \mathrm{cde}$ & $6.67 \pm 6.67 \mathrm{~d}$ & $18.67 \pm 4.81 \mathrm{efg}$ & I \\
\hline & 1.0 & $0.00 \pm 0.00 \mathrm{~d}$ & $20.00 \pm 11.55 \mathrm{~cd}$ & $40.00 \pm 11.55 \mathrm{abcd}$ & $33.33 \pm 6.67 \mathrm{bcde}$ & $40.00 \pm 20.00 \mathrm{abcd}$ & $26.67 \pm 7.06 \mathrm{defg}$ & II \\
\hline & 2.0 & $53.33 \pm 29.06 \mathrm{abc}$ & $40.00 \pm 0.00 \mathrm{abcd}$ & $20.00 \pm 11.55 \mathrm{bcd}$ & $33.33 \pm 17.64 \mathrm{bcde}$ & $13.33 \pm 13.33 \mathrm{~cd}$ & $32.00 \pm 4.00 \mathrm{cdef}$ & II \\
\hline & 3.0 & $26.67 \pm 17.64 \mathrm{abcd}$ & $60.00 \pm 23.09 \mathrm{ab}$ & $66.67 \pm 17.64 a$ & $66.67 \pm 24.04 \mathrm{ab}$ & $20.00 \pm 11.55 \mathrm{~cd}$ & $48.00 \pm 14.05 \mathrm{abc}$ & III \\
\hline \multirow{4}{*}{$\begin{array}{l}\text { Wild } \\
\text { capsicum }\end{array}$} & 0.5 & $20.00 \pm 0.00 \mathrm{bcd}$ & $13.33 \pm 6.67 \mathrm{~cd}$ & $6.67 \pm 6.67 \mathrm{~d}$ & $13.33 \pm 6.67 \mathrm{de}$ & $33.33 \pm 17.64 \mathrm{abcd}$ & $17.33 \pm 3.53 \mathrm{fg}$ & I \\
\hline & 1.0 & $33.33 \pm 24.04 \mathrm{abcd}$ & $6.67 \pm 6.67 \mathrm{~d}$ & $13.33 \pm 13.33 \mathrm{~cd}$ & $53.33 \pm 6.67 b c$ & $13.33 \pm 13.33 \mathrm{~cd}$ & $24.00 \pm 0.00 \mathrm{defg}$ & II \\
\hline & 2.0 & $60.00 \pm 30.55 \mathrm{ab}$ & $13.33 \pm 13.33 \mathrm{~cd}$ & $53.33 \pm 6.67 \mathrm{ab}$ & $20.00 \pm 0.00 \mathrm{cde}$ & $53.33 \pm 13.33 \mathrm{abc}$ & $40.00 \pm 6.93 \mathrm{bcd}$ & II \\
\hline & 3.0 & $13.33 \pm 6.67 \mathrm{bcd}$ & $20.00 \pm 11.55 \mathrm{~cd}$ & $13.33 \pm 6.67 \mathrm{~cd}$ & $40.00 \pm 0.00 \mathrm{bcde}$ & $73.33 \pm 6.67 \mathrm{a}$ & $32.00 \pm 4.62 \mathrm{cdef}$ & II \\
\hline \multirow{4}{*}{$\begin{array}{l}\text { Hill } \\
\text { glory } \\
\text { bower }\end{array}$} & 0.5 & $13.33 \pm 6.67 \mathrm{bcd}$ & $20.00 \pm 0.00 \mathrm{~cd}$ & $26.67 \pm 17.64 \mathrm{bcd}$ & $20.00 \pm 20.00 \mathrm{cde}$ & $26.67 \pm 6.67 \mathrm{bcd}$ & $21.33 \pm 5.82 \mathrm{defg}$ & II \\
\hline & 1.0 & $33.33 \pm 17.64 \mathrm{abcd}$ & $26.67 \pm 17.64 \mathrm{bcd}$ & $46.67 \pm 6.67 \mathrm{abc}$ & $53.33 \pm 6.67 b c$ & $40.00 \pm 20.00 \mathrm{abcd}$ & $40.00 \pm 4.62 \mathrm{bcd}$ & II \\
\hline & 2.0 & $33.33 \pm 6.67 \mathrm{abcd}$ & $46.67 \pm 6.67 \mathrm{abc}$ & $53.33 \pm 6.67 \mathrm{ab}$ & $46.67 \pm 17.64 \mathrm{bcd}$ & $13.33 \pm 6.67 \mathrm{~cd}$ & $38.67 \pm 8.11 \mathrm{bcde}$ & II \\
\hline & 3.0 & $73.33 \pm 13.33 a$ & $63.33 \pm 14.53 \mathrm{ab}$ & $46.67 \pm 6.67 \mathrm{abc}$ & $93.33 \pm 6.67 \mathrm{a}$ & $53.33 \pm 6.67 \mathrm{abc}$ & $66.00 \pm 3.06 \mathrm{a}$ & IV \\
\hline LSD & & 39.97 & 32.10 & 31.31 & 31.31 & 35.14 & 17.09 & \\
\hline $\mathrm{CV} \%$ & & 91.98 & 71.60 & 58.08 & 49.93 & 58.60 & 32.26 & \\
\hline
\end{tabular}

\section{Conclusion}

Based on the toxicity weed extracts through the direct toxic effect and residual effect (by adult emergence test and seed damage test and, against maize weevil, S. zeamais Motsch. wild capsicum was best and next was the swamp smartweed at $3 \%$. However, the toxicity order was wild capsicum (Croton bonplandianum) $>$ swamp smartweed (Polygonum coccineum $)>$ hill glory bower $($ Clerodendrum viscosum $)>$ water hyacinth $($ Eichhornia crassipes $)>$ ariach $($ Cassia tora). 


\section{Acknowledgment}

The authors sincerely acknowledge the Institute of Research and Training (IRT), Hajee Mohammad Danesh science and Technology University, Dinajpur, Bangladesh for its financial (17-18) supports for the research work.

\section{References}

Abebe, F., Tefera, T., Mugo, S., Been, Y. and Vidal. S. (2009). Resistance of maize varieties to the maize weevil, Sitophilus zeamais (Motsch.) (Coleoptera: Curculionidae). African Journal of Biotechnology. 8, 5937-5943.

Ahad, M.A., Nahar, M.K., Amin, M.R., Suh, S.J. and Kwon, Y.J. (2016a). Effect of weed extracts against pulse beetle, Callosobruchus Chinensis L. (Coleoptera: Bruchidae) of mung bean. Bangladesh J. Agril. Res. 41(1), 75-84.

Ahad, M.A., Bhuyain, M.M.H., Hoque, M. and Hoque, F. (2016b). Eco-friendly management of lesser grain borer, Rhizopertha dominica f. (bostrichidae: coleoptera) on Wheat in storage. American Journal of Life Science Researches. 4(4).

Alam, M.Z. (1971). Pest of stored grains and other stored products and their control. Agril. Inf. Serv. Dhaka. 6.

Arya, M. and Tiwari, R. (2013). Efficacy of some indigenous bioproducts against rice weevil, Sitophilus oryzae (Linn.) on wheat. Indian Journal of Applied Research. 3(6), 22-49.

Bosa, D. (2014). Pesticide free methods of maize weevil control in stored maize for developing countries. Graduate Theses and Dissertations. 14083. http://lib.dr. iastate.edu/ etd/14083

Binggeli, P. (1999). Lantana camara L. (Verbenaceae). Retrieved October 12, 2005 from http//www.memberslycos.co.uk/ woodyPlant Ecology/docs/web_spd.htm

Casey, Sclar, D. (1994). Neem: Mode of action of compounds presents in extracts and formulations of Azadirachta indica seeds and their efficacy to pests of ornamental plants and to non-target species. Retrieved October 12 , 2005 from http://www.colostate.edu/Depts/Entomology/Courses/en570/Papers_1994/sclar.html.

Das, D. (1998). Insecticidal and fungicidal activity of phosphorothioates of eugenol. Food Protectants and Infestation Control Department, Central Food Technological Research Institute, (CSIR), Mysore - 570 020, India. Journal of Pure and Applied Microbiology. 5(1), 307-311.

Dhliwayo, T. and Pixley, K. (2003). Divergent selection for resistance to maize weevil in six maize populations. Crop Sci. 43, 2043-2049.

Fragoso, D.B., Guedes, R.N.C. and Peternelli, L.A. (2005). Developmental rates and population growth of insecticide resistant and susceptible populations of Sitophilus zeamais. J. Stored Prod. Res. 41, 271-281.

Haque, M.T. and Hussain, M. (1993). Oviposition preference and growth of pulse beetle on some species of pulses. Bangladesh Journal of Nuclear Agriculture. 9, 47-53.

Heyde, J.V.D., Saxena, R.C. and Schmutterer, H. (1983). Neem oil and extracts as potential insecticides for control of Hemipterous, rice pests. In: Proceeding of second International Neem Conference, Rauischholzhausem, Germany, 337-390.

Kavita, H.N. (2004). Abiotic and biotic factors affect efficacy of chlorfenapyral for control of stored-product insect pests. Journal of Food Protection. 74(8), 1288-1299.

Kearney, J. (2010). Food consumption trends and drivers. Philos. Trans. R. Soc. Lond. B. Biol. Sci. 365, $2793-2807$. doi:10.1098/rstb.2010.0149

Khanam, L.A.M., Talukder, D., Khan, A.R. and Rahman, S.M. (1990). Insecticidal properties of Royna, Aphanamixis polystachya wall. Against Tribolium castaneum D. Journal of Asiatic Society of Bangladesh. 16, 71-74.

McDonald, L.L., Guy, R. and Speirs, R.D. (1970). Preliminary evaluation of new candidate materials as toxicants repellent and attractants against stored product insects. Marketing Research Report No: 82. Agril. Res. Service. US. Dept. of Agriculture Washington.

Mohale, S., Allotey, J. and Siame, B.A. (2010). Control of tribolium confusum J. Du val by diatomaceous earth on stored groundnut (Arachis hypogaea) and Aspergillus flavus link spore dispersal. African Journal Food Agriculture Nutrition and Development. 10(6), 2678-2694.

Nukenine, E.N. (2010). Stored product protection in Africa: Past, present and future. p. 425 10th International Working Conference on Stored Product Protection. Julius-Kühn-Archiv, Berlin, German. 
Padin, S., Dal Bello, G. and Fabricio, M. (2002). Grain loss caused by Tribolium casteneum, Sitophilus oryzae and Acanthoscelides obtectus in stored durum wheat and beans treated with Beauverica bassiana. J. Stored Prod. Res. 38, 69-74.

Pandey, N. and Brave, D. (2011). Phytochemical and Pharmacological Review on Annona squamosa Linn. 2(4), 14041412.

Pereira, C.J., Pereira, E.J.G., Cordeiro, E.M.G, Lucia, T.M.C.D., Totola, M.R. and Guedes, R. N.C. (2009). Organophosphate resistance in the maize weevil, Sitophilus zeamais: Magnitude and behavior. Crop Protection. 28, 168-173.

Perez, M.J., Flinn, P.W.W., Campbell, J.F., Hagstrum, D.W. and Throne, J.E. (2004). Detction of stored grain insect infestation in wheat transported in railroad hopper-cars. J. Eco. Entomol. 7, 1474-1483.

Phillips T.W. and Throne J.E. (2010). Biorational approaches to managing stored product insects. Ann. Rev. Entomol. 55 , 375-397.

Quasem, M.A. (1999). Maize production and marketing in Bangladesh: An indicative exercise. FMRSP Working Paper No. 14.

Sahayaraj, K. (1994). Antifeedant effect of some plant extracts on the Asian armyworm, Spodoptera litura (Fabricious). Current Sci. India. 74(6), 523-525.

Talukder, F.A. and Howse, P.F. (1993). Deterrent and insecticidal effects of extracts of pithraj, Aphanamixis polystachya (Meliaceae), against Tribolium castaneum in storage. J. Chem. Ecol. 19, 2463-2471.

Throne, J.E. (1994). Life history of immature maize weevils (Coleoptera: Curculionidae) on corn stored at constant temperatures and relative humidities in the laboratory. Env. Entomol. 23, 1459-1471.

Udo, I.O. (2005). Evaluation of the potential of some local spices as stored grain protectants against the maize weevil Sitophilus zeamais Motsch (Coleoptera: Curculionidae). Journal of Applied Science in Environmental Management. 9, 165-168.

Waliullah, T.M., Yeasmin, A.M., Ashraful, A., Wahedul, I.M. and Parvez, H. (2014). Insecticidal and Repellent Activity of Clerodendrum viscosum Vent. (Verbenaceae) Against Tribolium castaneum (Herbst) (Coleoptera: Tenebrionoidea). Academic J. Entomol. 7(2), 63-69.

Cite this article as: Fatematuzzjohora, Md. Abdul Ahad, Most. Rubiya Khatun and M. A. Hossain (2021). Evaluation of toxicity of five medicinal plant extracts on maize weevil, Sitophilus zeamais (Mots.) (Coleoptera: Curculionidae) on stored maize. International Journal of Agricultural Sciences and Technology. 1(2), 40-50. doi: 10.51483/ IJAGST.1.2.2021.40-50. 